\title{
Pelayanan Kesehatan Tradisional Bekam: Kajian Mekanisme, Keamanan dan Manfaat
}

\section{Traditional Cupping Therapy: A Review of Mechanism, Safety and Benefits}

\author{
Yenni Risniati ${ }^{1}$, Annisa R. Afrilia ${ }^{1}$, Tri W. Lestari ${ }^{1}$, Nurhayati ${ }^{1}$, Hadi Siswoyo ${ }^{1}$ \\ 1) Pusat Penelitian dan Pengembangan Sumber Daya dan Pelayanan Kesehatan, Jalan Percetakan Negara No. 29 Jakarta \\ 10560, Indonesia \\ Korespondensi: yrisniati@gmail.com, annisa.rizky.afrilia@gmail.com
}

Submitted: 3 September 2019, Revised: 2 Desember 2019, Accepted: 13 Desember 2019

https://doi.org/10.22435/jpppk.v3i3.2658

\begin{abstract}
Abstrak
Terapi bekam merupakan salah satu terapi kesehatan tertua di dunia. Hal ini dibuktikan, bekam sudah ada di dalam catatan kedokteran tertua Papyrus Ebers, yang ditulis 1550 SM pada era Mesir kuno. Terapi bekam sendiri terbagi menjadi dua jenis, yakni bekam basah dan bekam kering. Yang membedakan antara bekam basah dan bekam kering adalah keberadaan darah yang dikeluarkan. Kajian (review) ini bertujuan untuk mengetahui mekanisme, keamanan, dan juga manfaat bekam. Dari beberapa artikel penelitian yang telah didapatkan, umumnya dengan pemanfaatan bekam mendapatkan hasil yang baik. Sementara jumlah penelitian pemanfaatan bekam masih sedikit, sehingga masih diperlukan penelitian lebih lanjut untuk mendapatkan bukti yang lebih baik dan meyakinkan. Di Indonesia, pelayanan kesehatan tradisional bekam diatur dalam PMK 61 tahun 2016 tentang Pelayanan Kesehatan Tradisional Empiris. Secara regulasi pelayanan tradisional bekam tidak direkomendasikan karena termasuk ke dalam tindakan dengan perlukaan. Padahal, kenyataannya pelayanan tradisional bekam ini ada dan diminati oleh masyarakat. Melihat khasiat dan antusias masyarakat, diharapkan pelayanan tradisional bekam tetap dapat dilakukan di Griya Sehat dengan menjadikan faktor keamanan sebagai fokus utama dalam pelayanan. Hal ini tentunya dapat didukung dengan adanya pembinaan secara menyeluruh mengenai keamanan pelayanan kesehatan tradisional bekam terhadap para praktisi bekam.
\end{abstract}

Kata kunci: bekam, kesehatan tradisional, penyehat tradisional, manfaat terapi bekam

\section{Abstract}

Cupping therapy is one of the oldest health therapies in the world. This was proven by an ancient Egypt paper in 1550 SM as cupping was mentioned in their medical journal. Cupping therapy has been classified into two categories, which were wet and dry cupping. The difference between wet and dry cupping is the presence or absence of blood being released. This literature review aims to find out the history, development, and also the use of cupping. From some research articles that have been obtained, we generally get good results from the use of the cupping method. However, because research on cupping utilization is still limited, further research is needed to obtain better and more convincing evidence. Regulation of traditional cupping service is not recommended because it is an invasive action, when in fact this traditional cupping service exists and is in demand by the community. Seeing the efficacy and enthusiasm of the community, it is hoped that traditional cupping services can still be carried out in a griya sehat with regard to efficacy. Of course, can be supported by the existence of comprehensive guidance on the efficacy of traditional cupping health services for cupping practitioners.

Keywords: traditional health service, cupping, safety, benefits 


\section{Pendahuluan}

Bekam merupakan salah satu pelayanan kesehatan tradisional yang sedang berkembang di masyarakat Indonesia. Pelayanan kesehatan tradisional ini merupakan salah satu perawatan kesehatan tertua di dunia: berusia ribuan tahun dan telah dipraktikkan oleh berbagai macam peradaban besar kuno di dunia, termasuk Mesir, Persia, Babilonia, Cina, India, Yunani dan Romawi. Oleh karena itu, tidak mengherankan jika bekam diminati oleh semua kalangan. ${ }^{1}$

Bekam sudah dikenal sejak zaman dulu. Pada zaman Nabi Muhammad, beliau menggunakan tanduk kerbau atau sapi, tulang unta, gading gajah. ${ }^{2}$ Adapun masyarakat pada zaman Cina kuno menyebut hijamah sebagai "perawatan tanduk" karena tanduk menggantikan kaca. ${ }^{2}$ Sementara itu, orang-orang di Eropa menggunakan lintah sebagai alat untuk hijamah. ${ }^{2}$ Dalam artikelnya, Curtis mengemukakan bahwa bekam sudah ada di dalam catatan kedokteran tertua (Papyrus Ebers), yang ditulis 1550 SM pada era Mesir kuno. ${ }^{2}$

Papyrus Ebers sendiri ditulis dalam bahasa Mesir Kuno. Isinya menjelaskan praktik kedokteran pada zaman Mesir Kuno, yang mencakup ramuan pengobatan dan terapi dalam berbagai aspek, termasuk bekam. ${ }^{1}$ Dalam tulisan hieroglif di salah satu halaman Papyrus Ebers (dokumen sejarah yang ditemukan pada abad ke 16 SM, dan berisikan \pm 800 formula resep yang mencakup 700 macam/jenis bahan obat), dijelaskan bahwa bekam dapat digunakan sebagai terapi untuk gangguan menstruasi, demam, gangguan nafsu makan dan berbagai macam nyeri. Selain itu, bekam juga merupakan terapi suportif untuk mempercepat proses penyembuhan penyakit. Salah satu bukti yang menyatakan bahwa praktik bekam sudah ada pada zaman mesir kuno, yakni ukiran pada dinding kuil di Kom Ombo, daerah Aswan (Temple of Kom Ombo). Kuil ini dibangun pada dinasti Ptolemaic $\left(180\right.$ - 47 SM). ${ }^{1}$ Dokumentasi ukiran pada dinding Kuil Kombo seperti yang terlihat di Gambar 1.

Bekam tidak hanya berkembang di Asia, di negara-negara barat seperti Eropa dan Amerika melalui penelitian ilmiah, para ahli menyimpulkan fakta-fakta ilmiah bagaimana keajaiban bekam dapat menyembuhkan berbagai penyakit secara aman dan efektif dibandingkan metode kedokteran modern, sehingga saat ini banyak bermunculan ahli bekam di kota-kota besar Amerika dan Eropa. Beberapa ahli bekam di dunia barat yang melakukan penelitian, seperti (1) Dr. Michael Reed Garch dari California USA yang menulis buku Potent Poins a Guide to Self Care for Common Ailments (Titiktitik berkhasiat sebagai panduan perawatan diri dan pengobatan penyakit umum). (2) Cohler pada tahun 1990, melakukan penelitian tentang Bekam dan menulis buku "The Connective Tissue as The

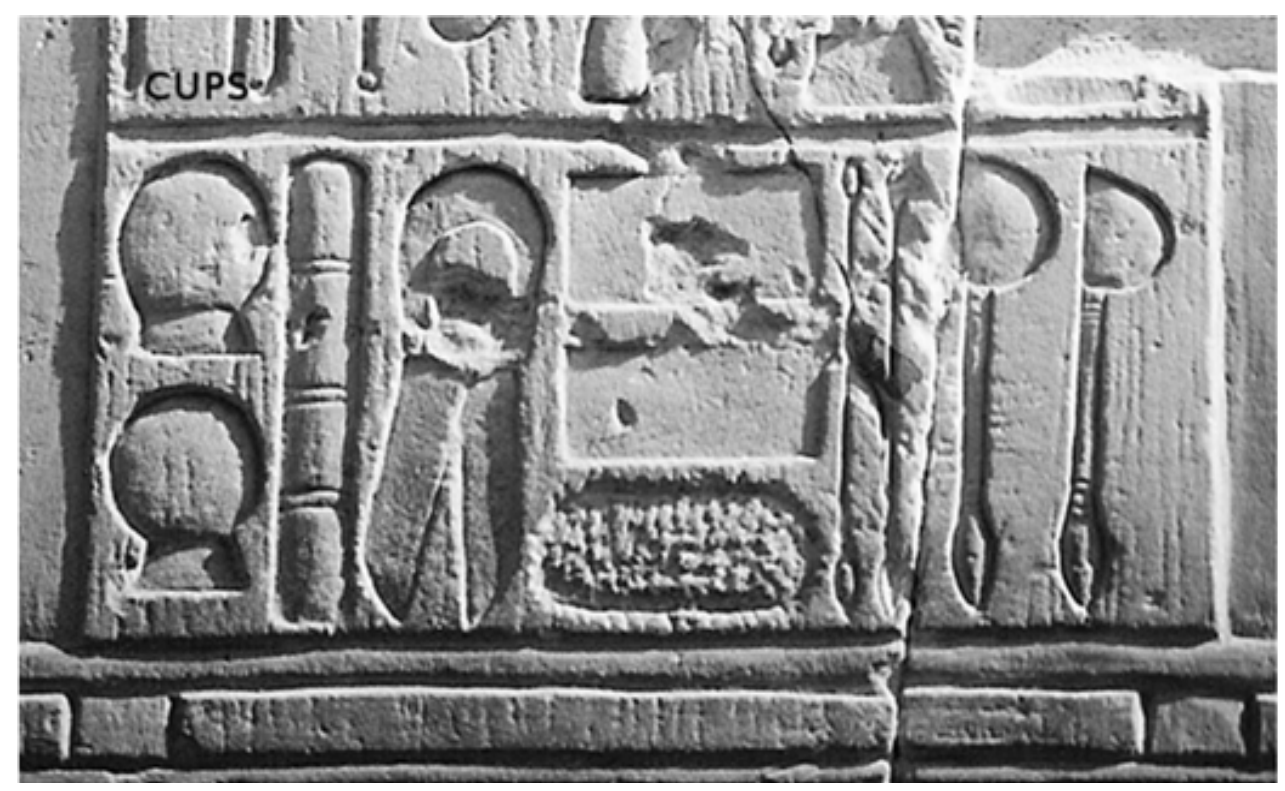

Gambar 1. Ukiran Hieroglif Pada Kuil Kom Ombo Dinasti Ptolemaic Mesir yang Menggambarkan Tentang Bekam ${ }^{1}$ 
Physical Medium for Conduction for Healing Energy Cupping Therapeutic Method" (jaringan ikat sebagai media fisik untuk menghantarkan energi pengobatan dengan bekam). (3) Anderson pada tahun 1985, membuat tulisan dengan judul "100 Diseases Treated by Cupping Method" (seratus penyakit dapat diobati dengan bekam). ${ }^{3}$

Bagaimana permulaan praktik bekam di Indonesia, tidak ada catatan resmi mengenai kapan metode pengobatan ini masuk ke Indonesia. Kemungkinan praktik bekam dimulai, semenjak masuknya para pedagang Gujarat dan Arab yang menyebarkan agama Islam ke Nusantara pada abad ke-12. Saat ini terapi bekam di Indonesia sudah banyak dikenal oleh masyarakat, dan hal ini di tandai dengan banyaknya jasa terapi bekam yang ditawarkan. ${ }^{4}$

Di Indonesia, orang yang memanfaatkan kesehatan tradisional (kestrad) cukup banyak. Dalam survey Riset Kesehatan Dasar (RKD) 2013, didapatkan 30,4\% keluarga di Indonesia memanfaatkan pelayanan kestrad (yankestrad). Adapun dalam RKD tahun 2018 didapatkan 31,4\% orang pernah memanfaatkan pelayanan yankestrad. Dari yang pernah memanfaatkan yankestrad, 98,5\% memanfaatkan pelayanan penyehat tradisional (hattra). Jenis upaya kestrad yang dimanfaatkan terbanyak $(65,3 \%)$ adalah keterampilan manual yang didalamnya termasuk bekam. Rata-rata biaya yang dikeluarkan oleh pengguna bekam Rp. 90.000 dengan kisaran harga Rp.0-Rp.200.000. ${ }^{5,6}$ Meskipun secara medis, belum banyak penelitian yang mengevaluasi manfaat bekam pada berbagai macam penyakit, tetapi banyak masyarakat menggunakannya dengan alasan keyakinan, keuangan, reaksi obat kimia dan tingkat kesembuhan. ${ }^{7}$ Pelayanan tradisional bekam ini menjadi salah satu terapi alternatif bagi masyarakat untuk pemeliharaan kesehatan, hal ini ditandai bahwa saat ini banyak pelatihan dan klinik bekam. Masyarakat meyakini bahwa darah yang dikeluarkan merupakan darah yang mengandung banyak toksin yang tidak diperlukan atau mengganggu kesehatan. Hal ini sesuai dengan penelitian yang dilakukan oleh Purboyekti pada tahun 2017 di kelurahan Pondok Benda, Pamulang bahwa $62,6 \%$ masyarakat setempat memilikipersepsi yang positif terhadap pelayanan tradisional bekam. ${ }^{8}$ Oleh sebab itu penulisan artikel ini bertujuan untuk memberikan gambaran mekanisme, keamanan dan manfaat pelayanan kesehatan tradisional bekam.

\section{Metode}

Metode pencarian artikel dalam kajian pustaka ini menggunakan artikel yang dipilih melalui mesin pencari, seperti Google Search, Google Scholar, Science Direct, Pubmed. Semula artikel yang dipilih didasarkan atas indeksasi Scopus. Namun, karena artikel-artikel mengenai bekam dan kesehatan tradisional masih tergolong sedikit, artikel-artikel yang tidak terindeks Scopus akhirnya dimasukkan kembali. Namun, artikel-artikel yang tidak terindeks Scopus dibatasi hanya pada jurnal yang mempunyai ISSN atau DOI. Hal ini dilakukan untuk menghindari artikel yang berasal dari jurnal palsu/predator.

Metode pencarian untuk buku dipilih penerbit yang sudah memiliki kredibilitas tinggi. Misalnya, dari World Health Organization (WHO), lembaga-lembaga di bawah Perserikatan Bangsa-Bangsa (PBB) lain selain WHO, buku yang diterbitkan oleh Kementerian Kesehatan (Kemenkes) RI maupun Negara lain dan yang dikeluarkan oleh perkumpulan-perkumpulan bekam. Kata kunci dalam pencarian yang digunakan antara lain "hystori of cupping therapy", "mechanism of cupping therapy", "hijamah", "traditional chinese medicine", "cupping therapy and traditional chinese medicine", "cupping therapy in primary health care", "bekam", "bekam di Indonesia", "peraturan pemerintah tentang kesehatan tradisional", "peraturan kesehatan tradisional".

\section{Hasil}

Hasil yang dipaparkan dikelompokkan berdasarkan mekanisme, keamanan dan manfaat bekam.

\section{Mekanisme}

Terapi bekam terbagi menjadi dua jenis, yakni bekam basah dan bekam kering. Bekam kering mencakup bekam luncur, bekam api, dan bekam tarik. Yang membedakan antara bekam basah dan bekam kering, adalah ada tidaknya darah yang dikeluarkan. Teknik bekam luncur dilakukan dengan meng-kop bagian tubuh tertentu, lalu meluncurkan kop tersebut ke bagian tubuh yang lain. Sedangkan bekam tarik dilakukan dengan cara 
meng-kop beberapa detik kemudian kop ditarik dan ditempelkan kembali pada kulit. ${ }^{9}$

Pada proses terapi pembekaman, terjadi bendungan lokal, di mana stimulasi titik meridian, menyebabkan hipoksia dan radang, sehingga dapat memperbaiki mikrosirkulasi dan fungsi sel dengan cepat. Lima belas hari setelah terapi bekam, terjadi peningkatan elastisitas spektrin yang dapat menstimulasi kerja sistem kekebalan tubuh: sel pembunuh alami (Natural Killer cells), sehingga daya tahan tubuh meningkat baik sebagai pencegahan maupun perlawanan terhadap penyakit. Meridian atau potent points merupakan suatu sistem saluran yang membujur dan melintang di seluruh tubuh yang secara kedokteran tidak terlihat nyata tetapi dapat dibuktikan keberadaannya dengan radioaktif teknesium perteknetat, yang menghubungkan permukaan tubuh dengan organ dalam tubuh, organ satu dengan organ lainnya, organ dengan jaringan penunjang-jaringan penunjang lainnya, sehingga membentuk suatu kesatuan yang bereaksi bersama apabila ada rangsangan dari kulit. Hasil penelitian Majid pada tahun 2009, menyatakan bahwa di bawah kulit, otot, maupun fascia terdapat suatu poin atau titik yang mempunyai sifat istimewa. Antara poin satu dengan poin lainnya saling berhubungan membujur dan melintang membentuk jaring-jaring (jala). Jala ini dapat disamakan dengan meridian. Dengan adanya jala maka ada hubungan yang erat antar bagian tubuh, sehingga membentuk satu kesatuan yang tak terpisahkan dan dapat bereaksi secara serentak. Kelainan yang terjadi pada satu poin dapat menular dan memengaruhi poin lainnya. Pengobatan pada satu titik juga bisa mengobati titik yang lain. Adapun penelitian yang dilakukan Hana pada tahun 2008, menyatakan bahwa prinsip bekam sama dengan prinsip akupunktur dan akupresur. ${ }^{10}$ Pada bekam basah terjadi pengeluaran darah, sedangkan pada akupunktur dan akupresur menggunakan penekanan dan stimulasi pada titik tertentu untuk mencapai hasil yang diinginkan. Pengeluaran darah (blood letting) itu sebenarnya merupakan salah satu teknik akupunktur tertua. Terapi bekam dilakukan pada area tertentu yang memiliki kesamaan dengan titik meridian. ${ }^{11}$

Ada beberapa teori yang menjelaskan mekanisme bekam, di antaranya teori Taibah dan teori Traditional Chinese Medicine (TCM). Menurut teori Taibah, terapi bekam merupakan sebuah tindakan bedah minor, di mana tekanan negatif (kekuatan isap) yang dilakukan di permukaan kulit menggunakan cup mengakibatkan kulit terisap ke dalam cup. Karena tekanan negatif ini membuat laju filtrasi kapiler menuju daerah cupping meningkat dan menurunkan absorbsi di kapiler vena yang meninggalkan daerah cupping. Proses ini diilustrasikan pada Gambar 2. ${ }^{12}$

Peningkatan filtrasi kapiler-kapiler kulit ini menyebabkan banyaknya cairan dan zat-zat berbahaya yang terfiltrasi menumpuk di daerah cupping. Selain itu, tekanan negatif ini juga akan mengumpulkan cairan limfe dan interstisial di daerah cupping. Subtansi kimia, mediator inflamasi, dan mediator nyeri akan merangsang ujung-ujung saraf sensoris di daerah cupping dan memutus adhesi jaringan, sehingga rasa nyeri berkurang. Proses ini diilustrasikan pada Gambar 3. ${ }^{12}$

Tindakan dengan perlukaan pada daerah cupping akan membuka barrier kulit untuk mengeluarkan cairan bersama zat-zat berbahaya dan mencegah absorbsinya di ujung kapiler vena. Tindakan dengan perlukaan pada daerah cupping ini mengakibatkan peningkatan pembersihan plasma darah dari material-material penyebab penyakit, seperti radikal bebas, kolesterol, dan zat-zat berbahaya lainnya. Proses ini diilustrasikan pada Gambar 4. ${ }^{12}$

Setelah dilakukan tindakan dengan perlukaan, tekanan negatif kembali diulang menggunakan cupping pada daerah tersebut. Tekanan negatif yang kedua kalinya ini mengakibatkan seluruh cairan yang terkumpul (bersama zat-zat berbahaya) keluar, sehingga seluruh cairan yang terkumpul pada area cupping habis. Pada tindakan cupping kedua, terjadi gradien tekanan yang sangat besar di ujung kapiler arteriol dan venula yang menyebabkan filtrasi pada kedua ujung kapiler tersebut. Proses ini diilustrasikan pada Gambar 5. ${ }^{12}$

Hal ini menyebabkan terjadinya peningkatan pembersihan plasma darah, yang ditandai dengan timbulnya luka pada jaringan tersebut. Luka tersebut secara fisiologis akan membaik karena proses hemostasis tubuh. Hemostasis fisiologi ini ditandai dengan munculnya cairan interstisial melalui filtrasi pada arteriol kapiler kulit setelah pembersihan cairan yang berisi zat-zat berbahaya sebelumnya. 


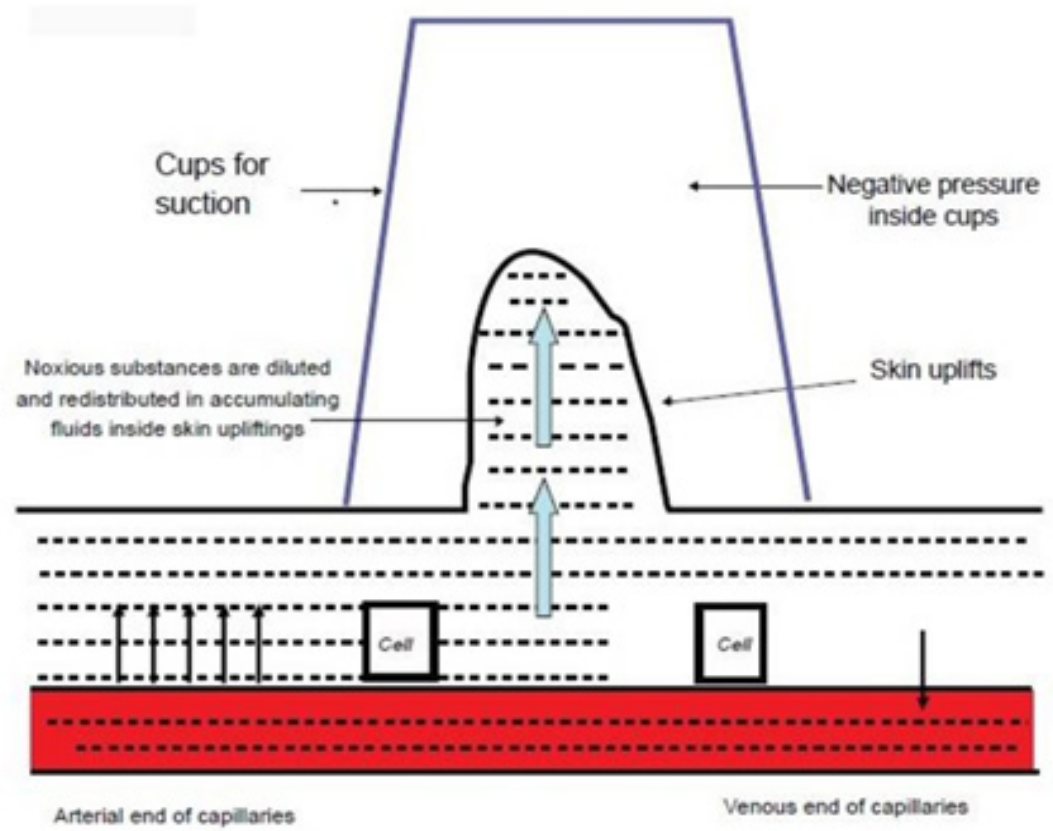

Gambar 2. Langkah Pertama dari Bekam: Tekanan Negatif Membuat Peningkatan Filtrasi Pada Ujung Kapiler Arteriol dan Menurunkan Absorbsi di Kapiler Vena Setelah Area Cupping. Cairan dan Zat-zat Berbahaya Mulai Menumpuk di Daerah Cupping ${ }^{12}$

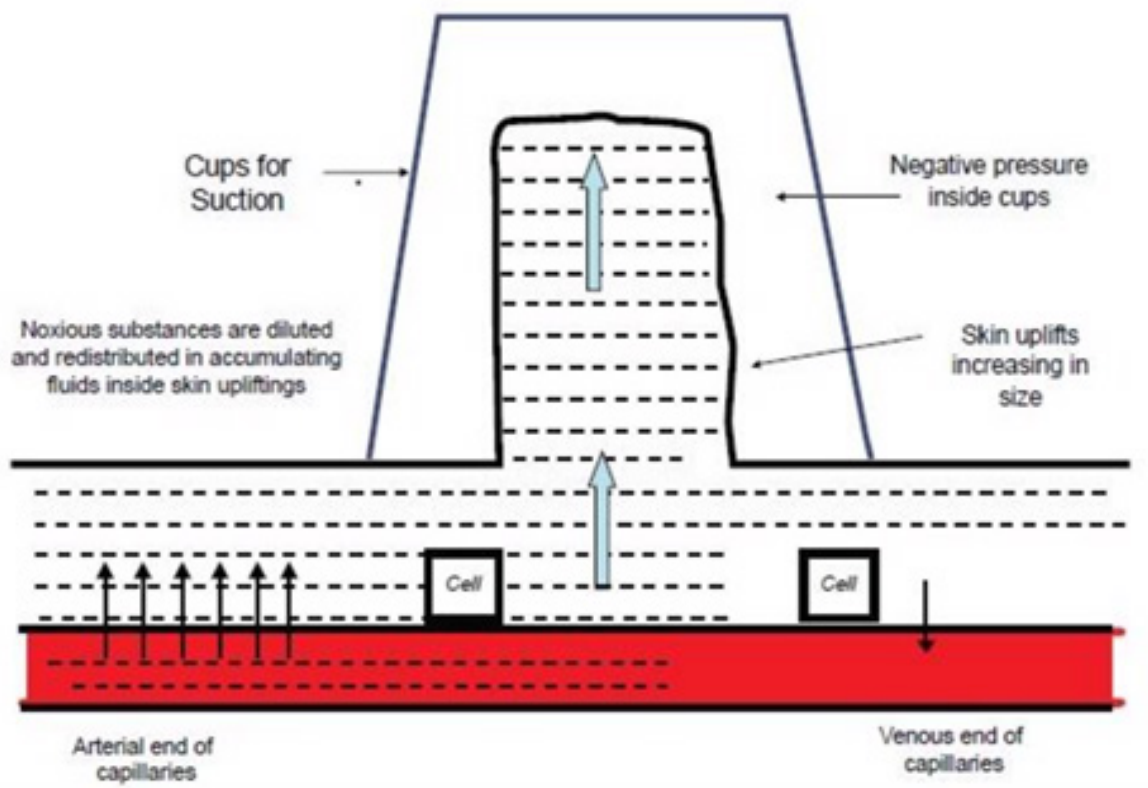

Gambar 3. Akhir Langkah Pertama dari Bekam Terkumpul oleh Peningkatan Filtrasi: Semakin Banyak Cairan dan Zat-zat Berbahaya yang Penurunan Absorbsi yang Menghasilkan Peningkatan Pembersihan Plasma Darah dan Cairan Interstisial ${ }^{12}$ 


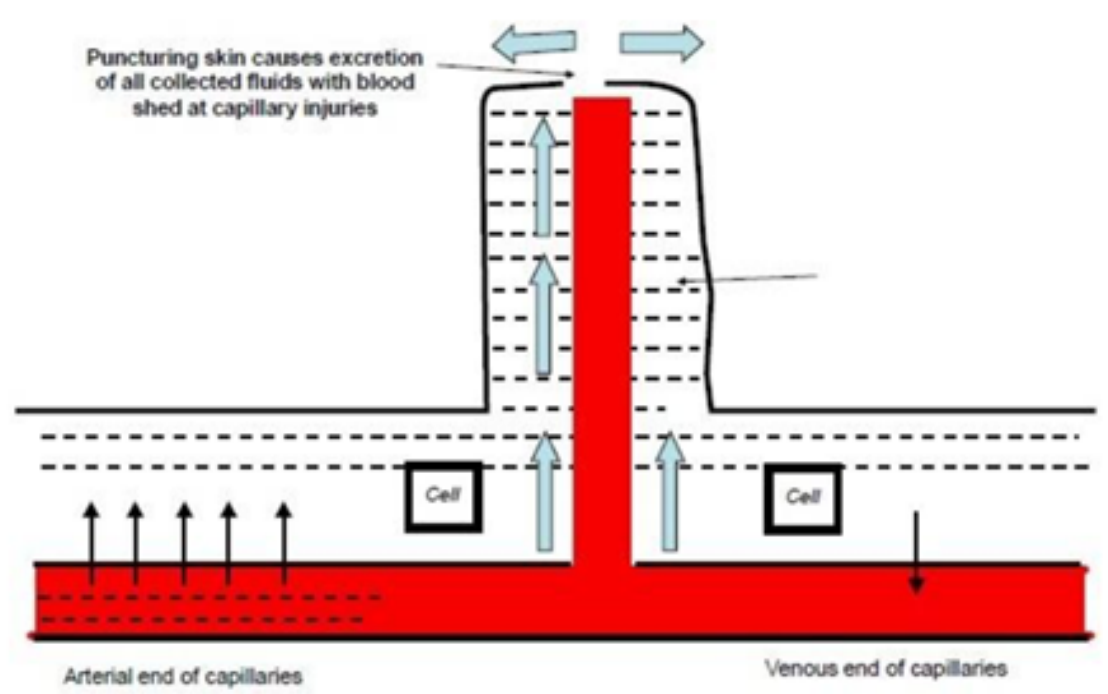

Gambar 4. Langkah Kedua Bekam: Penusukan Pada Area Cupping Membuat Cairan yang Terkumpul Mulai Keluar Bersama Plasma Darah, Cidera Penusukan Pada Kapiler Menyebabkan Peningkatan Pembersihan Zat-zat Penyebab Penyakit dari Plasma Darah ${ }^{12}$

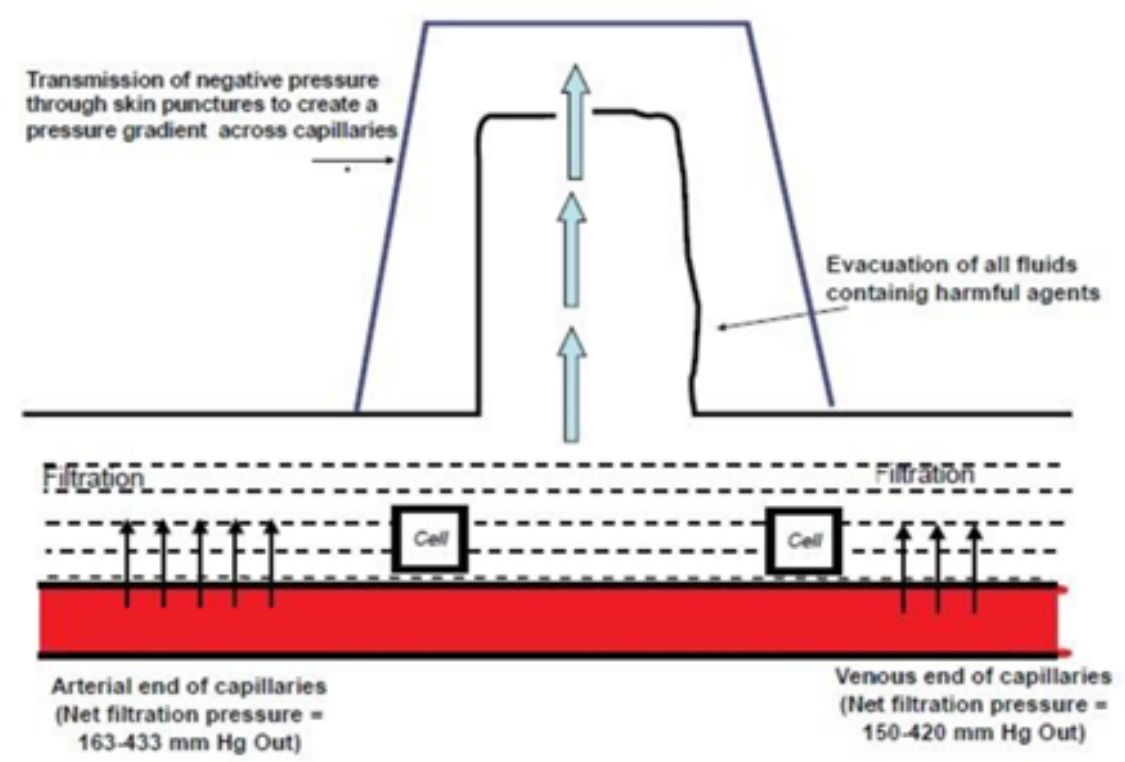

Gambar 5. Langkah Ketiga Bekam (Cupping Kedua): Pada Cupping Kedua, Tekanan Negatif Akan Mengakibatkan Cairan (Bersama Zat-zat Berbahaya) Keluar Seluruhnya. Perbedaan Gradien Tekanan Karena Tekanan Negatif yang Kedua Ini Mengakibatkan Peningkatan Filtrasi di Kedua Ujung Kapiler (Arteriol dan Venula) ${ }^{12}$

Proses ini diilustrasikan pada Gambar 6. ${ }^{12}$

Berdasarkan penjelasan di atas, dapat disimpulkan bahwa teori taibah merupakan teori bekam basah. Bekam basah mencakup 3 kegiatan, yaitu bekam kering, tindakan dengan perlukaan pada tempat yang di cupping dan pengeluaran darah dari tempat yang dilukai dengan melakukan cupping yang kedua dengan gelas yang sama dengan yang digunakan ketika melakukan bekam kering. Jadi, bekam basah sudah mencakup bekam kering dalam kegiatannya, sehingga diharapkan kondisikondisi yang terjadi ketika bekam kering dilakukan juga terjadi ketika melakukan bekam basah. Teori Taibah diajukan oleh Salah untuk menjelaskan 


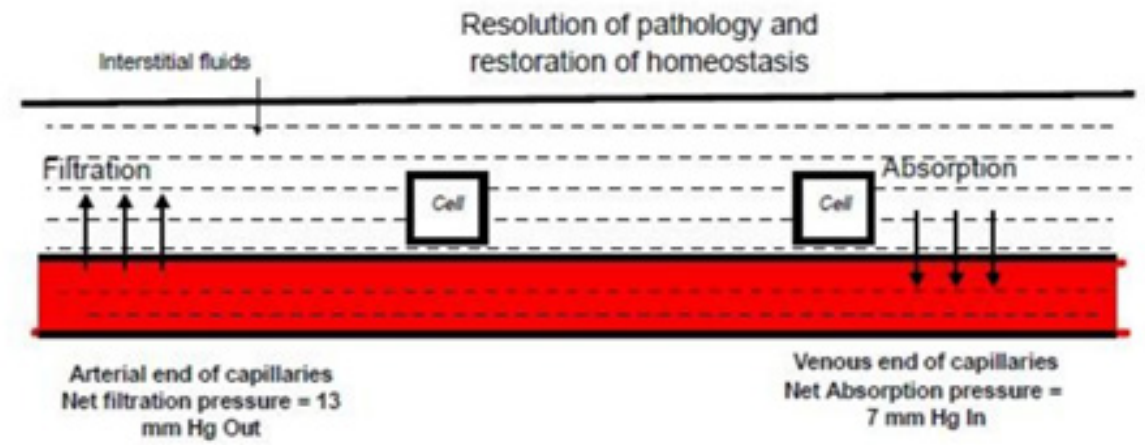

Gambar 6. Pemulihan Jaringan Secara Fisiologis: Setelah Zat-zat Berbahaya Dikeluarkan Bersamaan dengan Cairan yang Terkumpul, Pemulihan Jaringan Akan Terjadi Secara Fisiologis. Cairan Interstisial yang Baru Akan Terbentuk dari Filtrasi di Ujung Kapiler Arteriol. Cairan Interstisial yang Sebelumnya Banyak Mengandung Zat- zat Berbahaya, Kini Lebih Bersih Setelah Terjadi Ekskresi Zat-zat Tersebut Melalui Terapi Bekam ${ }^{12}$

teori mekanisme bekam basah dari sudut pandang kedokteran konvensional. Nama Taibah diambil dari Kota Taibah, Madinah Al Munawaroh. Kota tempat tinggal Rasulullah Salallahuálaihiwassallam. ${ }^{4}$

Sementara menurut teori Traditional Chinese Medicine (TCM) hanya sekali dilakukan cupping, yakni setelah dilakukan perlukaan, berbeda dengan teori Taibah yang melakukan cupping dua kali, sebelum dan setelah tindakan dengan perlukaan. ${ }^{13}$ Para praktisi TCM percaya bahwa penyakit disebabkan oleh terhentinya atau hambatan pada sumber energi vital atau Qi. Salah satu cara membuka hambatan Qi dan memulihkan keseimbangan agar aliran Qi kembali lancar adalah denganbekam. PrinsipbekamadalahmengaturQidan darah dengan mengusir dingin dan menghilangkan lembap, sehingga dengan bekam bisa mengusir angin, dingin, lembap dan melancarkan darah yang tergenang, terutama bila dilakukan bersama-sama dengan akupunktur. Apabila diandaikan dengan Yin dan Yang, Qi secara aktif hadir pada pada semua lakilaki dan perempuan. Yin merupakan Qi perempuan dan Yang merupakan Qi laki-laki. Dengan bekam, maka keseimbangan Qi bisa tercapai (Gambar 7).

Prinsip TCM ini belum sesuai dengan prinsip kedokteran yang harus berbasis bukti. Beberapa peneliti Cina sudah berusaha untuk menjelaskan prinsip mekanisme bekam dikaitkan dengan prinsip kedokteran, antara lain pendapat Hong dkk yang mengajukan prinsip bahwa bekam bekerja dengan menciptakan perubahan pada struktur jaringan

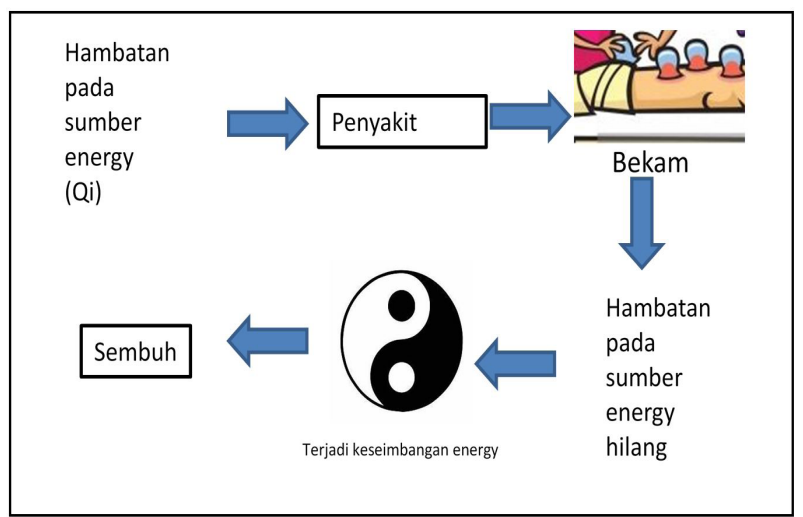

Gambar 7. Teori Bekam Menurut TCM ${ }^{9}$

lokal sebagai hasil dari tekanan negatif dari gelas yang digunakan. Perubahan ini meregangkan sarafsaraf dan otot yang mengakibatkan peningkatan sirkulasi darah dan otohemolisis. Namun, hingga saat ini belum ada keuntungan dari otohemolisis pada penyakit-penyakit yang menjadi indikasi bekam. ${ }^{10}$ Adapun Gao dkk mengajukan teori bahwa bekam pada titik akupunktur menyebabkan hiperemia dan hemostasis yang mempunyai efek terapi. Ada juga yang mengajukan teori bahwa bekam basah mempunyai efek analgesik. Bekam menimbulkan deformasi atau jejas pada kulit yang akan merangsang serat-serat $\mathrm{A} \beta$ pada area yang sakit dan juga pada bagian distal kulit yang sakit tersebut. Hal ini akan merangsang area inhibitor reseptif neuron-neuron di tanduk dorsal tulang belakang. Bekam juga merangsang pemulihan dan kenyamanan pasien. ${ }^{11}$ 
Bekam basah dapat didefinisikan sebagai suatu tindakan bedah minor yang dibuat untuk mengeluarkan zat-zat yang dianggap "sampah" dan beracun melalui perlukaan pada kulit superfisial untuk membuka tahanan kulit. Dengan membuat tekanan hingga kulit tertarik, maka cairan interstitial akan terkumpul di bawah kulit dan keluar dari kulit yang dilukai. Bersamaan dengan keluarnya cairan tersebut, sel-sel darah yang sudah rusak dan zat-zat yang dianggap beracun akan keluar bersama cairan. Proses ini diperkirakan mirip dengan cara kerja pembuluh darah dalam capsula bowman ginjal. ${ }^{14}$

\section{Keamanan}

\section{Indikasi dan Kontraindikasi Bekam}

Bekam dapat digunakan untuk penyakit yang sifatnya lokal maupun sistemik. Bekam dapat digunakan untuk mengurangi rasa sakit pada penyakit-penyakit seperti sakit kepala, carpal tunnel syndrome dan beberapa penyakit lokal lainnya. Sementara untuk penyakit sistemik, bekam banyak digunakan pada kasus-kasus hipertensi dan diabetes mellitus. Bekam tidak bisa dilakukan langsung di atas pembuluh darah vena dan arteri, nervus, pada kulit yang sedang mengalami inflamasi, lubang-lubang tubuh (lubang telinga, hidung), mata, kelenjar limfe, luka yang terbuka, tulang yang patah, luka bakar dan thrombosis vena dalam. Adapun penyakit-penyakit yang menjadi kontraindikasi untuk dilakukannya bekam dapat dikelompokkan menjadi kontraindikasi absolut dan relatif. Kontraindikasi absolut terjadi apabila dalam kondisi tersebut informasi mengenai keamanan bekam belum cukup diketahui (Tabel 1). ${ }^{16,17}$

\section{Efek samping dan Kejadian tidak diinginkan (Adverse Event)}

Efek samping yang ditimbulkan dari praktik bekam tidak berat, hanya menimbulkan rasa tidak nyaman yang akibat adanya bekas pembekaman dan penyayatan di kulit. Akan tetapi, bekas tersebut akan hilang dalam waktu 2-3 hari sehingga terapi bekam aman untuk dilakukan. ${ }^{18}$

Sementara kejadian tidak diinginkan yang dapat terjadi akibat bekam antara lain timbulnya jaringan parut, luka bakar, sakit kepala, gatal, pusing, rasa lelah, ketegangan otot, anemia, mual, pembentukan bula, hematoma, timbulnya sakit di tempat dilakukannya bekam, abses, infeksi kulit, insomnia, hiperpigmentasi, reflex vasovagal. Dalam sebuah systematic review dilaporkan belum didapatkan kejadian tidak diinginkan yang serius..$^{15,19,20}$

\section{Manfaat}

Dalam buku Ad Dawa'ul-Ajib yang ditulis oleh ilmuwan Damaskus Muhammad Amin Syaikhu, dari hasil penelitian tentang pengobatan dengan metode bekam pada tahun 2001 Masehi, sebanyak 300 kasus dan didapatkan data sebagai

Tabel 1. Indikasi dan Kontraindikasi Bekam

\begin{tabular}{ll}
\hline \multicolumn{1}{c}{ Indikasi bekam } & \multicolumn{1}{c}{ Kontraindikasi bekam } \\
\hline Indikasi penyakit lokal: & Kontraindikasi absolut: \\
- Sakit pinggang, leher, bahu, kepala & - Kanker \\
- Migrain & - Gagal organ (ginjal, hati dan jantung) \\
- Mengurangi sakit pada paralisis fasial, brakialgia, & - Menggunakan pacemaker \\
- carpal tunnel syndrome. & - Hemofilia \\
- Kekakuan otot & Kentraindikasi relatif: \\
- Mengurangi sakit pada herpes zoster & $\bullet$ Infeksi akut \\
Indikasi penyakit sistemik: & - Menggunakan antikoagulan \\
- Sakit kepala karena tekanan darah tinggi & $\bullet$ Mengalami penyakit kronik yang berat \\
- Kencing manis & - Hamil, nifas dan menstruasi \\
- Nyeri sendi & - Anemia \\
- Asma & $\bullet$ Baru saja menjalani bekam basah \\
- Anemia & $\bullet$ Baru mendonorkan darah \\
- Penyakit jiwa: cemas dan depresi & $\bullet$ Mengalami kegawatdaruratan \\
- Infertilitas & $\bullet$ Anak-anak dan orang tua \\
\hline
\end{tabular}


berikut: 1) Dalam kasus tekanan darah tinggi, tekanan darah turun hingga mencapai batas normal, 2) Dalam kasus tekanan darah rendah, tekanan darah naik hingga batas normal, 3) Jumlah sel-sel darah putih (leukosit) meningkat dalam $60 \%$ kasus dan masih dalam batas normal, 4) Kadar gula darah turun pada pengidap kencing manis dalam $92,5 \%$ kasus, 5) Jumlah asam urat di darah turun pada $83,68 \%$ kasus, 6) Pada darah bekam yang keluar, didapati bahwa eritrosit yang didalamnya berbentuk aneh, tidak berfungsi normal, mengganggu kinerja sel lain. ${ }^{3}$ Saat ini terapi bekam telah dimodifikasi sehingga teknis pelaksanaannya mengikuti kaidahkaidah ilmiah menggunakan alat yang praktis dan efektif. ${ }^{1}$

\section{Bekam Dalam Mengurangi Rasa Sakit}

Beberapa penelitian dan systematic review sudah dilakukan terkait dengan efektivitas bekam dalam mengurangi rasa sakit. ${ }^{14,21-23}$ Umumnya hasilhasil penelitian tersebut mendapatkan hasil yang baik. Namun metodologi penelitian artikel utama belum semuanya berhasil dalam meminimalisasi bias. Dalam systematic review yang sudah dilakukan ada yang kurang berhasil dalam mendapatkan jurnal dengan metodologi yang kuat, sehingga masih sulit untuk menyatakan bahwa bekam baik untuk mengurangi rasa sakit dengan bukti yang ada sekarang. ${ }^{22}$

Walaupun begitu sudah ada teori mekanisme kerja bekam terhadap penurunan rasa sakit, yaitu mengasumsikan bahwa bekam bermanfaat untuk manajemen sesuai teori TCM mengenai keseimbangan energi, rasa nyeri dianggap disebabkan gangguan sirkulasi darah dan kemacetan serta menghentikan ekstravasasi inflamasi (keluar dari cairan tubuh seperti darah) dari jaringan. Ada juga yang membuat teori bahwa bekam dapat memengaruhi sistem saraf otonom dan membantu mengurangi rasa sakit. Teori-teori ini belum didukung dengan hasil-hasil penelitian ilmiah. ${ }^{22}$

Adapun teori Taibah mengajukan teori bahwa efek mengurangi rasa sakit pada bekam dapat terjadi akibat perubahan sifat biomekanik kulit seperti yang dijelaskan oleh teori gerbang nyeri (pain-gate theory), kontrol penghambatan beracun berbahaya (Diffuse Noxious Inhibitory Controls), teori zona reflex (reflex zone theory). Transmisi nyeri menurut ketiga teori terjadi di saraf tulang belakang.
Dalam teori gerbang nyeri dinyatakan bahwa nyeri dipengaruhi oleh keseimbangan faktor-faktor yang mempengaruhi dan menghambat jaringan spinal dalam system somato sensory. Dalam teori kontrol penghambatan beracun berbahaya dinyatakan bahwa opioid yang dihasilkan dalam tubuh bisa menginisiasi penghambatan terhadap jalur nyeri di supraspinal. ${ }^{23-26}$

\section{Bekam Dalam Pengendalian Penyakit Kardio- vaskular}

Penggunaan bekam untuk melakukan kontrol terhadap tekanan darah cukup banyak. Beberapa penelitian mendapatkan hasil bekam efektif dalam menurunkan dan mengontrol tekanan darah sistolik. Namun untuk tekanan darah diastolik hanya efektif untuk mengontrol saja dan kurang efektif menurunkannya. Dalam penelitian-penelitian tersebut juga didapatkan tidak ada kejadian tidak diinginkan serius yang terjadi. ${ }^{13,27,28}$ Bekam juga ditemukan bekam juga dapat memperbaiki irama jantung pada kasus-kasus aritmia dan dapat mengurangi rasa tidak nyaman pada kasus angina dengan mengeliminasi mediator-mediator inflamasi yang dapat membahayakan mikrosirkulasi. Namun penelitian mengenai efek bekam terhadap irama jantung dan beberapa kelainan mikrosirkulasi lainnya selain hipertensi masih sedikit sehingga perlu perlu eksplorasi lagi untuk mendapatkan bukti yang lebih baik dan meyakinkan. ${ }^{29-31}$

\section{Bekam Dalam Pengendalian Diabetes Melitus}

Bekam basah bisa digunakan dalam pengobatan pasien dengan diabetes mellitus (DM). bekam basah membersihkan darah pasien diabetes dari disease related substances (DRS) seperti advanced glycation end products (AGEPs) yang bisa memperburuk prognosis pasien DM. Manfaat bagi pasien DM bisa didapat apabila bekam diberikan bersama-sama dengan diet, obat-obatan hipoglikemik ataupun costus (sejenis tanaman yang mempunyai efek hipoglikemik). Dengan melakukan bekam diharapkan dapat mencegah ataupun menunda komplikasi.

Bekam juga dapat digunakan dalam mengobati kaki diabetes. Pada pasien dengan kaki diabetes terjadi penumpukan cairan interstisial yang bersifat hiperglikemik. Hal ini mengakibatkan 
infeksi lebih mudah terjadi, sirkulasi darah menjadi buruk, neuropati, dan penumpukan AGEPs. Lama kelamaan akan timbul iskemia dan gangren. Dengan melakukan bekam, dapat mengurangi hal-hal yang menyebabkan timbulnya iskemik dan gangren tersebut. Pengobatan bekam untuk kaki diabetes harus atas monitoring dari spesialis bedah vaskular atau dokter ahli yang berhak menanganinya. Lokasi bekam pun tidak harus dilakukan di kaki, tetapi bisa di tempat-tempat bekam biasa dilakukan misalnya kepala, leher, dan tepi tulang belakang. ${ }^{32,33}$

Pada tahun 2019, Subhi melakukan penelitian terapi bekam dengan menilai perbedaan kadar gula darah pasien diabetes melitus. Hasil penelitian tersebut menunjukkan adanya perbedaan kadar gula darah sewaktu sebelum dan sesudah dilakukan bekam. Hal ini menunjukkan bahwa terapi bekam memiliki pengaruh terhadap penurunan kadar gula darah penderita diabetes melitus. Penelitian lain juga dilakukan oleh Jansen pada tahun 2013 yang menilai efektivitas terapi bekam terhadap penurunan tekanan darah setelah dilakukan terapi bekam, mendapatkan hasil bahwa bekam sangat berpengaruh terhadap penurunan tekanan darah pada penderita hipertensi primer. ${ }^{18}$

\section{Pembahasan}

Pengobatan tradisional di Indonesia secara umum, termasuk bekam di dalamnya diatur dalam Peraturan Pemerintah (PP) No. 103 tahun 2014 Pelayanan Kesehatan Tradisional. secara teknis dijelaskan dalam Peraturan Menteri Kesehatan (PMK) No. 61 tahun 2016 tentang Pelayanan Kesehatan Tradisional Empiris. Sesuai PMK 61/ tahun 2016, di Indonesia penyehat tradisional hanya boleh melakukan tindakan tanpa perlukaan. Untuk bekam, tindakan tanpa perlukaan hanya ada pada bekam kering saja, sedangkan bekam basah termasuk dalam tindakan dengan perlukaan. Pada saat Peraturan Menteri ini mulai berlaku, pengobat tradisional yang telah memberikan pelayanan kesehatan tradisional bersifat perlukaan dan memiliki Surat Izin Pengobat Tradisional (SIPT) berdasarkan Keputusan Menteri Kesehatan Nomor 1076/Menkes/SK/VII/2003 tentang Penyelenggaraan Pengobatan Tradisional, untuk diakui sebagai tenaga kesehatan tradisional harus telah mengikuti Rekognisi Pembelajaran Lampau
(RPL) paling sedikit jenjang 5 Kerangka Kualifikasi Nasional Indonesia (KKNI) atau lulus pendidikan minimal diploma 3 yang sesuai, paling lambat 17 Oktober 2020.34-37

Mekanisme bekam yang saat ini dikenal adalah teori TCM dan teori Taibah. Keduanya hanya memiliki sedikit perbedaan. Dalam TCM kebanyakan yang dilakukan adalah bekam kering walaupun kadang juga dilakukan bekam basah, sedangkan dalam Taibah yang dilakukan adalah bekam basah dengan 2 kali cupping. Diketahui bahwa bekam dapat mengeluarkan zat-zat toksik dan juga mengaktivasi zat-zat inflamasi sehingga dengan melakukan bekam seseorang dapat merasa lebih sehat dan stamina menjadi lebih baik..$^{9,12}$

Berdasarkan model pelayanannya, bekam basah dapat dianggap suatu tindakan bedah minor (incisi). oleh karena itu bekam basah hanya bisa dilakukan oleh tenaga kesehatan. Walaupun tindakan dalam bekam keamanannya baik dan bahkan belum dilaporkan kejadian tidak diinginkan yang serius, namun bila dilakukan pada orang-orang dengan kelainan tertentu (misal hemofilia atau anemia) bisa terjadi hal-hal yang membahayakan..$^{15,19,20}$

Dalam kedokteran, bekam banyak digunakan dalam membantu mengurangi rasa sakit pada pasien-pasien yang kurang responsif terhadap obat-obat analgetik seperti pada pasien kanker. Selain itu efek inflamasi setelah bekam yang menyebabkan vasodilatasi pembuluh darah banyak dimanfaatkan dalam mengontrol hipertensi. Aktivasi zat-zat inflamasi juga diketahui dapat memperlancar sirkulasi darah sehingga bekam juga dinilai baik dalam memperlambat proses kaki diabetikum pada pasien diabetes melitus dan juga mengobati kaki diabetik. $^{13,27,28,32,33}$

\section{Kesimpulan}

Dari beberapa sumber penelitian yang telah didapatkan umumnya dengan terapi bekam mendapatkan hasil yang baik. Karena mekanisme bekam meyakini bahwa darah yang dikeluarkan merupakan darah yang mengandung banyak toksin yang tidak diperlukan atau mengganggu kesehatan. Sementara penelitian pemanfaatan bekam masih sedikit, sehingga masih diperlukan penelitian lebih lanjut untuk mendapatkan bukti yang lebih baik dan meyakinkan. Adapun pemanfaatan bekam untuk 
penanganan penyakit, seperti DM, hipertensi, dapat diberikan bersama dengan terapi konvensional, diimbangi penerapan pola hidup sehat, supaya dapat mencegah atau menunda terjadinya komplikasi. Sementara untuk Adverse event (kejadian tidak diinginkan), dari hasil penelusuran didapatkan hasil dalam sebuah systematic review, dilaporkan belum didapatkan kejadian tidak diinginkan yang serius.

Secara regulasi pelayanan tradisional bekam tidak direkomendasikan karena termasuk ke dalam tindakan dengan perlukaan, padahal kenyataannya pelayanan tradisional bekam ini ada dan diminati oleh masyarakat. Hal ini didukung oleh data dari asosiasi Perkumpulan Bekam Indonesia (PBI), jumlah praktisi yang menjadi anggotanya tercatat sebanyak 3700 orang di seluruh Indonesia. ${ }^{8}$

\section{Saran}

Melihat khasiat dan antusias masyarakat, pelayanan tradisional bekam ini dapat dijadikan peluang untuk meningkatkan kesehatan masyarakat menjadi lebih baik, sehingga pelayanan tradisional bekam tetap dapat dilakukan di Griya Sehat dengan menjadikan faktor keamanan sebagai fokus utama dalam pelayanan. Hal ini tentunya dapat didukung dengan adanya pembinaan secara menyeluruh mengenai keamanan pelayanan kesehatan tradisional bekam terhadap para praktisi bekam, sehingga masyarakat yang akan memanfaatkan pelayanan tradisional bekam dapat terjamin keamanannya.

\section{Daftar Rujukan}

1. Nickel JC, Abdel-Halim RE. Re: Management of urinary tract infections: Historical perspective and current strategies: Part 1 - Before antibiotics [4] (multiple letters) [Abstrak]. J Urol [Internet]. 2005 [diakses pada 14 Februari 2020];173(1):21-6. Tersedia pada: https:// pubmed.ncbi.nlm.nih.gov/15592018/

2. Ratna Sari F, Salim MA, Ekayanti F, Subchi I. Bekam sebagai kedokteran profetik dalam tinjauan hadis, sejarah dan kedokteran berbasis bukti. Edisi kesatu. Ratna Sari F [editor]. Depok: Rajawali Pers [Internet]; 2018 [diakses pada 14 Februari 2020]. Halaman 1-10. Tersedia pada: http://repository.uinjkt.ac.id/ dspace/bitstream/123456789/49086/2/11.\%20 Buku\%20Bekam\%20Final\%20Rajawali.pdf
3. Rahman MA. Pengaruh terapi bekam terhadap tekanan darah pada pasien hipertensi di klinik bekam Abu Zaky Mubarak [Skripsi]. Ciputat: FKIK UIN Syarif Hidayatullah Jakarta [Internet]; 2016 [diakses pada 14 Februari 2020]. Tersedia pada: http://repository.uinjkt. ac.id/dspace/bitstream/123456789/30634/1/ MUHAMMAD\%20ALFIAN\%20RAHMANFKIK.pdf

4. Nurul F. Pengaruh terapi bekam basah terhadap kadar kolesterol total pada klien diabetes mellitus tipe 2 di desa Kaliwining, Kecamatan Rambipuji, Kabupaten Jember [Skripsi]. Jember: Universitas Negeri Jember [Internet]; 2015 [diakses pada 14 Februari 2020]. Tersedia pada: http://repository.unej.ac.id/bitstream/ handle/123456789/65725/112310101010. pdf? sequence $=1 \&$ is Allowed $=\mathrm{y}$

5. Kementerian Kesehatan RI. Farmasi dan pelayanan kesehatan tradisional dalam: Riset Kesehatan Dasar 2013. Jakarta: Badan Penelitian dan Pengembangan Kesehatan [Internet]; 2013 [diakses pada 14 Februari 2020]. h. 79-81. Tersedia pada: http://labdata.litbang.kemkes. go.id/images/download/laporan/RKD/2013/ Laporan_riskesdas_2013_final.pdf.

6. Kementerian Kesehatan RI. Pelayanan kesehatan tradisional dalam: Laporan Nasional Riset Kesehatan Dasar 2018. Jakarta: Lembaga Penerbit Badan Penelitian dan Pengembangan Kesehatan [Internet]; 2019 [diakses pada 14 Februari 2020]. h. 271-9. Tersdia pada: http:// labdata.litbang.kemkes.go.id/images/download/ laporan/RKD/2018/Laporan_nasional RKD2018FINAL.pdf

7. Trisnawati E, Jenie IM. Terapi komplementer terhadap tekanan darah pada penderita hipertensi: A literatur review. J Keperawatan Respati Yogyakarta [Internet]. 2019 [diakses pada 7 Februari 2020];6(3):641. Tersedia pada: http://nursingjurnal.respati.ac.id/index.php/ JKRY/article/view/370/pdf

8. Lestari TW, Lusitawati, Afrilia AR, Suharyanto F, Prihartini N, Nurhayati, et al. Kepatuhan praktisi terapi tradisional bekam terhadap standar prosedur operasional. Holistik J Kesehatan,. 2019;13(2):114-27.

9. Damayanti S, Maharini F, Gunawan B. Profil 
penggunaan terapi bekam di Kabupaten/ Kota Bandung ditinjau dari aspek demografi, riwayat penyakit, dan profil hematologi. Acta Pharm Indones [Internet]. 2012 [diakses pada 14 Februari 2020];37(3):102-9. Tersedia pada: http://journals.itb.ac.id/index.php/acta/article/ view/4051/2170

10. Santoso H, Nugroho W, Santosa BJ, Wijono HTH, Sukardi H, Suryono A, et al. Pengaruh bekam terhadap peningkatan sel $\mathrm{T}$ CD8+ sebagai mekanisme pertahanan tubuh. J Penelit Kesehat Suara Forikes [Internet]. 2011 [diakses pada 14 Februari 2020];III(4):219-23. Tersedia pada: http://journals.itb.ac.id/index.php/acta/ article/view/4051/2170

11. Irawan H, Ari S. Pengaruh terapi bekam terhadap penurunan tekanan darah pada klien hipertensi. J Ilmu Kesehat [Internet]. 2012 [diakses pada 14 Februari 2020];1(1):31-7.

12. El Sayed SM, Mahmoud HS, Nabo MM. Medical and scientific bases of wet cupping therapy (al- hijamah): In light of modern medicine and propheticmedicine. Alternative and Integrative Medicine [Internet]. 2013 [diakses pada 14 Februari 2020]; 5(2): 1-16. Tersedia pada: https://www.hilarispublisher. com/open-access/medical-and-scientificbases-of-wet-cupping-therapy-al-hijamahin-light-of-modern-medicine-and-propheticmedicine-2327-5162.1000122.pdf

13. Aleyeidi N, Aseri K, Kawthar A. The efficacy of wet cupping on blood pressure among hypertension patients in Jeddah, Saudi Arabia: A Randomized Controlled Trial Pilot Study. Alternative \& Integrative Medicine [Internet]. 2015 [diakses pada 14 Februari 2020];4(1):1-4. Tersedia pada: https://www. hilarispublisher.com/open-access/the-efficacyof-wet-cupping-on-blood-pressure-amonghypertension-patients-in-jeddah-saudi-arabia-arandomised-controlled-trial-pilot-study-2327-5162.1000183.pdf

14. Sm ES, Hs M, Mmh N. Medical and scientific bases of wet cupping therapy ( al-hijamah ): In light of modern medicine and prophetic medicine. Alternative and Integrative Medicine. 2013;2(5).

15. Cao H, Han M, Zhu X, Liu J. An overview of systematic reviews of clinical evidence for cupping therapy. J Tradit Chinese Med Sci [Internet]. ScienceDirect. 2015 [diakses pada 14 Februari 2020];2(1):3-10. Tersedia pada: https://reader.elsevier.com/read$\mathrm{er} / \mathrm{sd} / \mathrm{pii} / \mathrm{S} 2095754815000277$ ? token $=\mathrm{B}-$ 0D6A3E8C8CB521BF0D259A9F3C48BC44498B76535EA717D1559F0F1ADDB7B 9A 0AB 1204B5B516AB 003F 4E 5D 1A10DEEB8

16. Aboushanab TS, AlSanad S. Cupping therapy: An overview from a modern medicine perspective. JAMS J Acupunct Meridian Stud [Internet]. 2018 [diakses pada 14 Februari 2020]; 11(3):83-7. Tersedia pada: https://reader.elsevier.com/reader/sd/pii/S2095754815000277?to$\mathrm{ken}=72001414$ CB 241 F D B 8533 D $2 \mathrm{CD} 6 \mathrm{~A}$ EEDB $610 \mathrm{E} 144 \mathrm{CF} 59 \mathrm{DE} 7 \mathrm{E}$ $9231 \mathrm{C} 63$ A 2800 A AB 77F 8 D 01 B 90 EBCE8ECE7267572C1C85F92674

17. Jadhav DK. Cupping therapy: An ancient alternative medicine. J Phys Fitness, Med Treat Sport [Internet]. 2018 [diakses pada 14 Februari 2020];3(1):1-4. Tersedia pada: https:// juniperpublishers.com/jpfmts/pdf/JPFMTS. MS.ID.555601.pdf

18. Rini TP, Karim D, Novayelinda R, Riau U. Gambaran kadar kolesterol pasien yang mendapatkan terapi bekam. JOM PSIK [Internet]. 2014 [diakses pada 14 Februari 2020];1(2):1-8. Tersedia pada: https://media. neliti.com/media/publications/186838-IDgambaran-kadar-kolesterol-pasien-yang-me.pdf

19. Cao H, Han M, Li X, Dong S, Shang Y, Wang $\mathrm{Q}$, et al. Clinical research evidence of cupping therapy in China: A systematic literature review. BMC Complement Altern Med [Internet]. 2010 [diakses pada 14 Februari 2020];10. Tersedia pada: https://pubmed.ncbi.nlm.nih. gov/21078197/

20. Student UH, Saleem M, Hani U. Review on cupping therapy (al-hijama): A miraculous alternative system of medicine, which is an unbeatable cure for all ailments. $2406 \sim$ J Pharmacogn Phytochem [Internet]. 2019 [diakses pada 14 Februari 2020];8(2):240614. Tersedia pada: http://www.phytojournal. com/archives/2019/vol 8 is sue $2 /$ 
PartAM/8-1-215-975.pdf

21. Kim JI, Kim TH, Lee MS, Kang JW, Kim KH, Choi JY, et al. Evaluation of wet-cupping therapy for persistent non-specific low back pain: A randomised, waiting-list controlled, open-label, parallel-group pilot trial. Trials [Internet]. 2011 [diakses pada 14 Februari 2020];12(1):146. Tersedia pada: https://www.ncbi.nlm.nih.gov/ pmc/articles/PMC3141528/pdf/1745-6215-12146.pdf

22. Kim JI, Lee MS, Lee DH, Boddy K, Ernst E. Cupping for treating pain: A systematic review. Evidence-based Complement Altern Med [Internet]. 2011 [diakses pada 14 Februari 2020];2011(January 2009). Tersedia pada: https://www.ncbi.nlm.nih.gov/pmc/articles/ PMC3136528/pdf/ECAM2011-467014.pdf

23. Al-Bedah AMN, Elsubai IS, Qureshi NA, Aboushanab TS, AliGIM, El-OlemyAT, etal. The medical perspective of cupping therapy: Effects and mechanisms of action. J Tradit Complement Med [Internet]. 2019 [diakses pada 14 Februari 2020];9(2):90-7. Tersedia pada: https://www. researchgate.net/publication/324838865 The_medical_perspective_of_cupping therapy_Effects_and_mechanisms_of_action/ link/5ae8d7f945851588dd8155c4/download

24. Costigan M, Woolf CJ. No dream, no pain: Closing the spinal gate. Cell [Internet]. 2002 [diakses pada 7 Februari 2020];108(3):297-300. Tersedia pada: https://www.cell.com/action/ showPdf?pii=S0092-8674\%2802\%2900640-2

25. Campbell CM. Ethnic differences in diffuse noxious inhibitory controls. University of Florida [Internet]; 2007 [diakses pada 14 Februari 2020]. Tersedia pada: https://www. ncbi.nlm.nih.gov/pmc/articles/PMC2597628/ pdf/nihms64628.pdf

26. Khalil MKM, AlSanad S. The compound effect of cupping therapy: Searching beyond the meridians. J Acupunct Res [Internet]. 2018 [diakses pada 14 Februari 2020];35(3):101-3. Tersedia pada: https://www.e-jar.org/upload/ pdf/jar-35-3-101.pdf

27. Zarei M, Hejazi S, Javadi A. GW27-e0802 The Efficacy of wet cupping in treatment of hypertension. J Am Coll Cardiol [Internet]. 2016 [diakses pada 14 Februari 2020];68(16):C140.
Tersedia pada: https://www.researchgate.net/ publication/309001997_GW27-e0802_The Efficacy_of_wet_cupping_in_treatment_of_ hypertension

28. Al-Tabakha MM, Sameer FT, Saeed MH, Batran RM, Farajallah NTA. Methodology used in the study [Abstrak]. J Pharm Bioallied Sci [Internet]. 2018 [diakses pada 14 Februari 2020];10(1):1-6. Tersedia pada: http://www. jpbsonline.org/printarticle.asp?issn $=0975$ 7406; year $=2018$; volume $=10 ;$ issue $=1$; spage $=1$; page $=6$; aulast $=$ Al-Tabakha; type $=0$

29. Arslan M, Yeşilçam N, Aydin D, Yüksel R, Dane S. Wet cupping therapy restores sympathovagal imbalances in cardiac rhythm [Abstrak]. J Altern Complement Med [Internet]. 2014 [diakses pada 7 Februari 2020];20(4):318-21. Tersedia pada: https://pubmed.ncbi.nlm.nih.gov/24520978/

30. Adel Galal BR. Islamic wet cupping and risk factors of cardiovascular diseases: Effects on blood pressure, metabolic profile and serum electrolytes in healthy young adult men. Altern Integr Med [Internet]. 2014 [diakses pada 5 Februari 2020];03(01):1-7. Tersedia pada: https://www.hilarispublisher.com/open-access/ islamic-wet-cupping-and-risk-factors-ofcardiovascular-diseases-2327-5162.1000151. pdf

31. NasratAM. Role of blood-let out cupping therapy in angina and angina risk management. Gen Med Open Access [Internet]. 2015 [diakses pada 5 Februari 2020];03(03):10-2. Tersedia pada: https://www.longdom.org/open-access/role-ofbloodlet-out-cupping-therapy-in-angina-andangina-risk-management-2327-5146-1000191. pdf

32. Mahmoud HS, El-Naga MA, Omar NAA, ElGhazawwy HA, Fathy YM, Nabo MMA, et al. Anatomical sites for practicing wet cupping therapy (al-Hijamah): In light of modern medicine and prophetic medicine. Altern Integr Med. 2013;02(08).

33. Nasrat AM, Nasrat RM, Nasrat MM. A therapeutic answer for the controversy of insulin cardio-protection among dysglycemic patients. Gen Med Open Access [Internet]. 2015 [diakses pada 5 Februari 2020];03(04):8-12. Tersedia pada: https://www.longdom.org/open-access/a- 
therapeutic-answer-for-the-controversy-ofinsulincardioprotection-among-dysglycemicpatients-2327-5146-1000216.pdf

34. Pemerintah Republik Indonesia. PP RI No. 103 Tahun 2014 Tentang Pelayanan Kesehatan Tradisional. Hukum Online [Internet]. 2014 [diakses pada 14 Februari 2020]. h. 1-39. Tersedia pada: https://www.hukumonline. com/pusatdata/detail/1t54a2598774348/node/ $1 \mathrm{t} 52 \mathrm{~d} 643 \mathrm{dfec} 005 / \mathrm{pp}-$ no-103-tahun-2014pelayanan-kesehatan-tradisional

35. Kementerian Kesehatan RI. Peraturan Menteri Kesehatan Republik Indonesia Nomor 61 tahun 2016 tentang Pelayanan Kesehatan Tradisional Empiris. Kementrian Kesehatan RI [Internet]. 2016 [diakses pada 14 Februari 2020]. Tersedia pada: https://www.persi.or.id/images/regulasi/ permenkes/pmk612016.pdf

36. Kementerian Kesehatan RI. Peraturan Menteri Kesehatan Republik Indonesia Nomor 15 Tahun 2018 Tentang Penyelenggaraan Pelayanan Kesehatan Tradisional Komplementer. Kementerian Kesehatan RI [Internet]. 2018 [diakses pada 14 Februari 2020]. h. 2-29. Tersedia pada: http://ditjenpp.kemenkumham. go.id/arsip/bn/2018/bn940-2018.pdf

37. Kementerian Kesehatan RI. Peraturan Menteri Kesehatan Nomor 37 tentang Pelayanan Kesehatan Tradisional. Kementerian Keseharan RI [Internet]. 2017 [diakses pada 14 Februari 2020]. Tersedia pada: https://peraturan.bpk. go.id/Home/Details/112104/permenkes-no-37tahun-2017 